\title{
PENGEMBANGAN MEDIA PEMBELAJARAN NGANGGUNG SEBAGAI ALTERNATIF PEMBELAJARAN BERBICARA DI KELAS RENDAH
}

\author{
Maulina Hendrik ${ }^{1}$, Sasih Karnita Arafatun ${ }^{2}$ \\ STKIP Muhammadiyah Bangka Belitung \\ maulina.hendrik@stkipmbb.ac.idl .; sasih.karnitaarafatun@stkipmbb.ac.id ${ }^{2}$
}

\begin{abstract}
This study aims to determine: 1) the profile of learning to speak students in low class; (2) the development plan of learning media of Nganggung as an alternative of speaking in low class; (3) development and assessment of learning media Nganggung as an alternative to learning to speak in low class. The method used in this research is Research and Development method with Hannafin \& Peck development design. Hannafin \& Peck model consists of three stages or phases, namely: the stage of needs analysis, design phase, and development stage. Needs analysis phase is done to know the learning profile of low grade students. After the learning profile data is obtained, the next step is to design or design the media in accordance with the needs in the field. Media design is done by creating Program Outline $(G B P)$ and media script. Designing media requires collaboration with material and media experts. Therefore, researchers conducted interviews / discussions with 3 expert material and 3 expert media learning. GBP design results and media manuscripts become the foundation to develop products in the form of learning media. After the product is developed, the next step is to test or assess the product by some media experts and material experts, each of them 3 people who have competence in the field of low-grade learning materials and culture-based learning media Nganggung. The result of the assessment shows that the development of learning media of Nganggung is feasible to be used as an alternative to low-level speech learning, especially the learning of Curriculum 2013.
\end{abstract}

Keywords: learning media, nganggung, learning to speak

\begin{abstract}
ABSTRAk: Penelitian ini bertujuan untuk mengetahui: 1) profil pembelajaran berbicara siswa di kelas rendah; (2) rancangan pengembangan media pembelajaran Nganggung sebagai alternatif pembelajaran berbicara di kelas rendah; (3) pengembangan dan penilaian media pembelajaran Nganggung sebagai alternatif pembelajaran berbicara di kelas rendah. Metode yang digunakan dalam penelitian adalah metode Penelitian dan Pengembangan (Research and Development) dengan desain pengembangan Hannafin \& Peck. Model Hannafin \& Peck terdiri atas tiga tahap atau fase, yaitu: tahap analisis kebutuhan, tahap desain, serta tahap pengembangan. Tahap analisis kebutuhan dilakukan untuk mengetahui profil pembelajaran berbicara siswa kelas rendah. Setelah data profil pembelajaran diperoleh, langkah selanjutnya ialah mendesain atau merancang media sesuai dengan kebutuhan di lapangan. Rancangan media dilakukan dengan membuat Garis Besar Program (GBP) dan naskah media. Merancang media memerlukan kerja sama dengan para ahli materi maupun media. Oleh karena itu, peneliti melakukan wawancara/ diskusi dengan 3 expert materi dan 3 expert media pembelajaran. Hasil rancangan GBP dan naskah media menjadi landasan mengembangkan produk berupa media pembelajaran. Setelah produk dikembangkan, langkah selanjutnya adalah melakukan pengujian atau penilaian produk oleh beberapa ahli media dan ahli materi, masing-masing sebanyak 3 orang yang memiliki kompetensi di bidang materi pembelajaran kelas rendah dan media pembelajaran berbasis budaya Nganggung. Hasil penilaian menunjukkan pengembangan media pembelajaran Nganggung layak digunakan sebagai alternatif pembelajaran berbicara di kelas rendah khususnya pembelajaran Kurikulum 2013.
\end{abstract}

Kata kunci: media pembelajaran, Nganggung, pembelajaran berbicara 


\section{PENDAHULUAN}

Bahasa memiliki peranan penting dalam kehidupan manusia yaitu sebagai sarana komunikasi. Hal tersebut terjadi karena sebagai makhluk sosial, manusia selalu berkomunikasi dengan orang lain sebagai wujud interaksi. Dalam lingkungan pendidikan, bahasa merupakan pengantar pendidikan. Bahasa memiliki empat aspek kemampuan yang mencakup menyimak, berbicara, membaca dan menulis harus dikembangkan (Resmini \& Juanda, 2007: 2).

Siswa harus menguasai keempat aspek tersebut agar terampil berbahasa. Salah satu aspek berbahasa yang harus dikuasai oleh siswa adalah berbicara, sebab keterampilan berbicara menunjang keterampilan lainnya (Tarigan, 2008:1). Keterampilan berbicara merupakan salah satu aspek keterampilan berbahasa yang sangat diperlukan dalam berkomunikasi. Seperti yang diungkapkan Prihatiningsih (2009: 2) bahwa "keterampilan berbicara dipandang memiliki peranan sentral dalam tujuan pembelajaran bahasa, karena hakikat belajar bahasa ialah belajar komunikasi, komunikasi lisan." Selain itu, berbicara menurut Tarigan (dalam Solchan, 2008: 12) adalah "kemampuan mengucapkan bunyi-bunyi artikulasi atas kata- kata untuk mengekspresikan, menyatakan, serta menyampaikan pikiran, gagasan dan perasaan.”.

Widawati (2010: 4) berpendapat bahwa tujuan berbicara adalah untuk menginformasikan, melaporkan sesuatu hal pada pendengar. Sesuatu tersebut dapat berupa, menjelaskan sesuatu proses, menguraikan, menafsirkan, atau menginterpretasikan sesuatu hal, memberi, menyebarkan, atau menanamkan pengetahuan, menjelaskan kaitan, hubungan, relasi antara benda, hal, atau peristiwa.

Sudiana (2011: 4) mengemukakan bahwa, faktor penunjang kemampuan berbicara, utamanya adalah model yang digunakan, yaitu model yang dapat mendukung peningkatan kemampuan berbicara siswa. Menciptakan sebuah pembelajaran yang menyenangkan (enjoyable learning) merupakan sebuah tantangan, guru haruslah mampu melakukan orkestrasi terhadap segala kemampuan yang ada menjadi sebuah kekuatan pembelajaran total.

Widyantoro (2011) mengemukakan bahwa, ada tiga faktor penyebab gangguan dalam kegiatan berbicara, yaitu: fisik, media, dan psikologis.

Peraturan Pemerintah No. 19 tahun 2005 BAB IV pasal 19 menyatakan bahwa Proses pembelajaran pada satuan pendidikan diselenggarakan secara interaktif, inspiratif, menyenangkan, menantang, memotivasi peserta didik untuk berpartisipasi aktif, serta memberikan ruang yang cukup bagi prakarsa, kreativitas, dan kemandirian sesuai dengan bakat, minat, dan perkembangan fisik serta psikologis peserta didik.

Berdasarkan hasil observasi dan wawancara di lapangan, menunjukkan bahwa masih terdapat ketidakberhasilan siswa dalam belajar khususnya kemampuan berbicara yang rendah. Siswa sulit mengemukakan pendapatnya walaupun dalam tingkatan yang sederhana, misalnya siswa diminta untuk mengenalkan diri dan dilanjutkan menceritakan pengalaman masing-masing di hadapan teman sekelas. Jika dipersentasekan $70 \%$ masih tersipu malu untuk tampil dan berbicara.

Ketidakberhasilan siswa disebabkan oleh beberapa faktor, di antaranya: pertama, beberapa guru di kelas rendah belum menyadari sepenuhnya bahwa keterampilan berbicara sangat besar pengaruhnya terhadap pembelajaran di kelas pada pelajaran apa pun. Kedua, keterampilan guru dalam menggunakan metodemetode pembelajaran sangat monoton sehingga siswa merasa bosan dan terfokus hanya pada materi yang 
dipelajari dalam satu sumber saja. Selain kedua penyebab di atas, peneliti juga menemukan penyebab lainnya, siswa belum mampu berbicara dengan baik dikarenakan kurangnya media yang digunakan guru dalam pembelajaran sehingga pembelajaran terkesan monoton.

Keterampilan mengembangkan dan menggunakan media pembelajaran merupakan salah satu keterampilan yang sangat penting untuk dimiliki oleh guru. Penggunaan media pembelajaran yang tepat dapat membantu siswa dalam memahami materi pelajaran serta dapat dijadikan sebagai alat untuk memotivasi siswa sehingga tujuan pembelajaran tercapai. Guru dituntut untuk dapat melaksanakan proses pembelajaran disertai dengan improvisasi, kreasi, menarik dan menyenangkan.

Menurut Arsyad (2002: 52) dalam buku Media Pembelajaran membagi media berdasarkan indera yang terlibat yaitu: media audio, visual, audio visual. Roestiyah (2008: 154) memberikan enam alasan mengenai kelebihan penggunaan media pembelajaran, yaitu: dapat menyimpan pendapat dari beberapa informasi, dapat memilih informasi tersebut dengan kecepatan yang tinggi, dapat menyajikan pada peserta didik dengan tanda diagram yang menantang, dapat memberi jawaban tipe kebutuhan peserta didik, dapat memberi umpan balik kepada peserta didik secara individual secepatnya, memiliki sejumlah perbedaan dengan peserta didik yang berbeda-beda.

Nganggung adalah budaya masyarakat Bangka yang sudah menjadi tradisi masyarakat di Bangka secara turun-temurun (Sudikan, 2001: 2-4). Nganggung adalah makanan yang dibawa dengan menggunakan sebelah tangan kanan, "dianggung". Orang Bangka dulu selalu bermusyawarah untuk memutuskan sesuatu, dan untuk menentukan alat yang akan dipergunakan dalam membawa makanan, masyarakat menemukan alat yang dinamakan dulang. Kemudian masyarakat menemukan sesuatu untuk dijadikan penutup dulang yang disebut tudung saji.

Penelitian pengembangan media pembelajaran telah banyak dilakukan oleh peneliti-peneliti sebelumnya, namun khusus untuk pengembangan media pembelajaran Nganggung belum pernah dilakukan. Oleh karena itu, untuk mengkaji lebih jauh mengenai pengembangan media pembelajaran tersebut guna meningkatkan keterampilan berbicara siswa, maka dilakukan penelitian untuk mengetahui: (1) profil pembelajaran siswa kelas 1 khususnya keterampilan berbicara di SD se-Kota Pangkalpinang; (2) rancangan dan desain pengembangan media pembelajaran Nganggung untuk pembelajaran berbicara siswa di kelas rendah; (3) pengembangan dan penilaian formatif media pembelajaran Nganggung untuk pembelajaran berbicara siswa di kelas rendah.

\section{METODE PENELITIAN}

Penelitian ini menggunakan metode Penelitian dan Pengembangan (Research and Development) dengan desain model Hannafin \& Peck. Hannafin \& Peck (dalam Sugiyono, 2012: 45) mendefinisikan "model Hannafin and Peck adalah model desain pengajaran yang terdiri dari tiga fase yaitu fase analisis kebutuhan, fase desain, fase pengembangan dan implementasi." Dalam model ini, penilaian dan pengulangan dijalankan dalam setiap fase. Model ini lebih berorientasi pada produk.

Sumber data dalam penelitian ini adalah pendidik/guru di kelas 1 sebanyak 3 orang yang tersebar di SD Negeri 6 Pangkalpinang, SD Negeri 17 Pangkalpinang, dan SD Negeri 56 Pangkalpinang. Selain itu, ahli media dan ahli materi masing-masing sebanyak 3 orang. Instrumen yang digunakan dalam tahap pengumpulan data adalah lembar observasi, pedoman wawancara, dan instrumen penilaian. 
Analisis penelitian ini menggunakan teknik analisis kualitatif deskriptif. Teknik analisis data dilakukan dengan mengelompokan informasi dari data kualitatif yang berupa masukan, tanggapan, kritik, dan saran perbaikan yang terdapat pada instrumen. Hasil analisis ini kemudian digunakan untuk merevisi produk yang dikembangkan. Dalam teknik analisis data ini, data diklsifikasikan dan dianalisis berdasarkan rumusan masalah penelitian.

\section{HASIL DAN PEMBAHASAN}

Hasil penelitian dan pembahasan penelitian ini meliputi: profil pembelajaran berbicara siswa SD kelas 1, desain media, pengembangan dan penilaian formatif media pembelajaran Nganggung sebagai alternatif pembelajaran berbicara siswa kelas rendah.

Profil pembelajaran berbicara siswa SD kelas 1 merupakan gambaran keseluruhan analisis kebutuhan yang meliputi: dokumen/perangkat pembelajaran, kegiatan pembelajaran, dan hasil wawancara. Hasil yang diperoleh: (a) Kurikulum yang digunakan adalah Kurikulum 2013; (b) Indikator dan tujuan pembelajaran yang diuraikan dalam RPP sesuai dengan Kompetensi Inti dan Kompetensi Dasar yang diharapkan; (c) Terdapat ketidaksamaan penjabaran indikator antarguru di tiga lokasi penelitian tersebut. Ditemukan bahwa perencanaan pembelajaran yang disusun belum mengolaborasikan ketiga aspek kemampuan dalam satu pertemuan, yaitu: aspek kognitif, psikomotor, dan afektif. Rencana kegiatan pembelajaran di setiap pertemuan hanya menghasilkan satu aspek kemampuan; (d) Metode pembelajaran/pengajaran yang digunakan dalam menyampaikan materi pelajaran menggunakan metode metode ceramah dan diskusi; (e) Kegiatan pembelajaran yang tergambar dalam rencana pembelajaran tidak menggunakan langkah-langkah pemebelajaran saintifik; (f) Media pembelajaran yang digunakan dalam pembelajaran adalah media gambar dan papan tulis.

Berdasarkan analisis di atas, dapat disimpulkan bahwa kemampuan berbicara siswa selama pembelajaran belum tampak aktif seperti yang telah direncanakan dalam dokumen perencanaan. Hal tersebut disebabkan kurangnya variasi metode pembelajaran dan media pembelajaran dari guru yang membuat siswa termotivasi untuk aktif berbicara.

Setelah memperoleh gambaran tentang profil pembelajaran berbicara siswa SD kelas 1, tahap selanjutnya dalam penelitian ini adalah merancang atau mendesain media dari kebutuhan yang diperoleh. Proses merancang melibatkan para ahli media dan materi yang berkompeten di bidang masingmasing. Langkah-langkah pertama yang dilakukan dalam mendesain media dan materi adalah membuat Garis Besar Perencanaan (GBP) baik media maupun materi pembelajaran. Garis Besar Perencanaan (GBP) merupakan gambaran secara umum desain media maupun materi pembelajaran. Dengan demikian, langkah pertama yang dilakukan peneliti adalah menganalisis kompetensi dasar dan indikator berdasarkan kebutuhan guru dan siswa.

Indikator pembelajaran di kelas 1 yang menghasilkan keterampilan berbicara pada tema Peristiwa Alam, di antaranya: Pendidikan Pancasila dan Kewarganegaraan (memainkan peran tentang terjadinya peristiwa alam seperti korban banjir), Bahasa Indonesia (menyebutkan bagian-bagian tubuh; menyebutkan kebutuhan tubuh agar tetap sehat; menyebutkan contoh benda berbentuk bulat, segitiga, tabung, kubus, kotak, dan balok; menyebutkan contoh benda padat dan benda cair yang ada di lingkungan sekitar; menyebutkan namanama tokoh dalam cerita; menyebutkan nama-nama tempat dalam cerita; menyebutkan urutan peristiwa; 
mengajukan pertanyaan berkenaan dengan sifat-sifat tokoh; menyebutkan bagian-bagian tubuh dirinya; menyebutkan bagian-bagian tubuh hewan dan tumbuhan yang utama); Matematika (menyebut penjumlahan dua bilangan; menyebutkan banyak benda; menyebutkan banyak benda dengan ciri tertentu dari sekumpulan benda).

Setelah menganalisis kompetensi dasar dan indikator pembelajaran, maka langkah berikutnya adalah merencanakan media atau papan cerita. Papan cerita atau disebut juga naskah media adalah bentuk penyajian materi pembelajaran melalui media rancangan yang merupakan penjabaran dari pokok-pokok materi yang telah disusun secara baik. Agar materi pembelajaran dapat disampaikan melalui media, maka media tersebut perlu dituangkan dalam gambar dan tulisan yang disebut naskah program media. Naskah program media adalah sebagai penuntun kita dalam memproduksi media. Secara teknis, penulisan naskah program media dalam penelitian ini adalah membuat sketsa media dan menyiapkan alat serta bahan. Setelah mendesain media pembelajaran, langkah selanjutnya adalah mendesain materi pembelajaran berdasarkan hasil analisis KD dan indikator.

Setelah membuat naskah media (story board) baik berupa media maupun materi pembelajaran, langkah selanjutnya adalah mengembangkan naskah media tersebut menjadi wujud yang sebenarnya. Hasil pengembangan media pembelajaran nganggung tersebut digambarkan sebagai berikut.
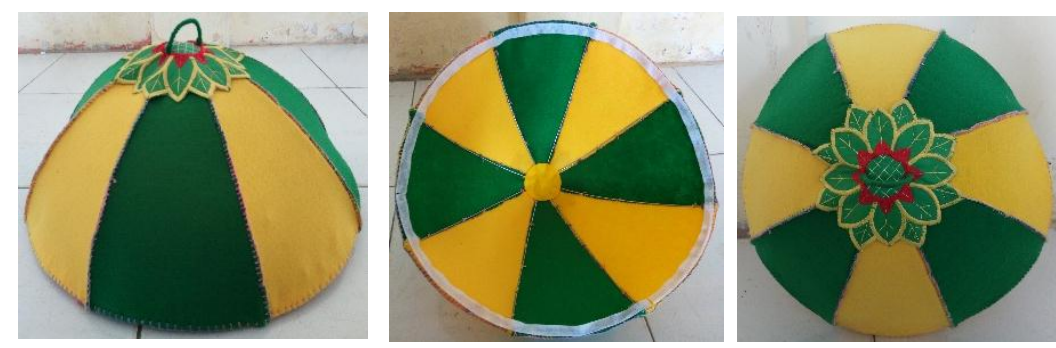

Gambar Media (Tudung Saji)
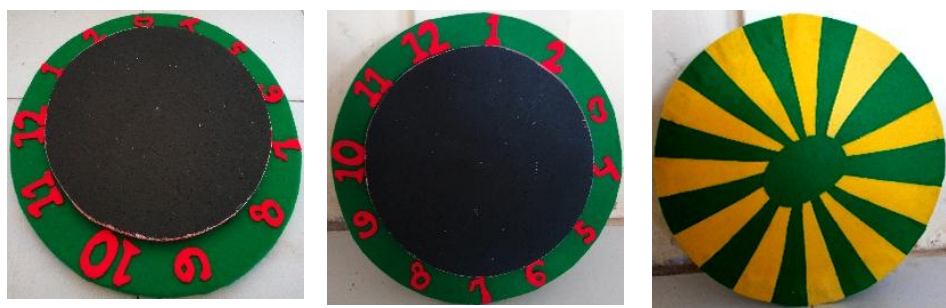

Gambar Media (Dulang)

Setelah mengembangkan media pembelajaran tersebut, langkah selanjutnya adalah mengembangkan naskah materi pembelajaran. Hasil pengembangan materi pembelajaran digambarkan sebagai berikut. 


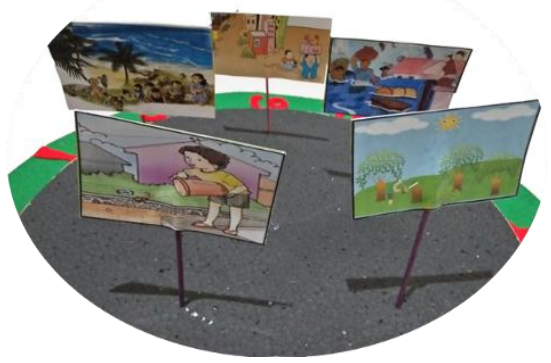

Gambar Materi (Peristiwa Banjir)

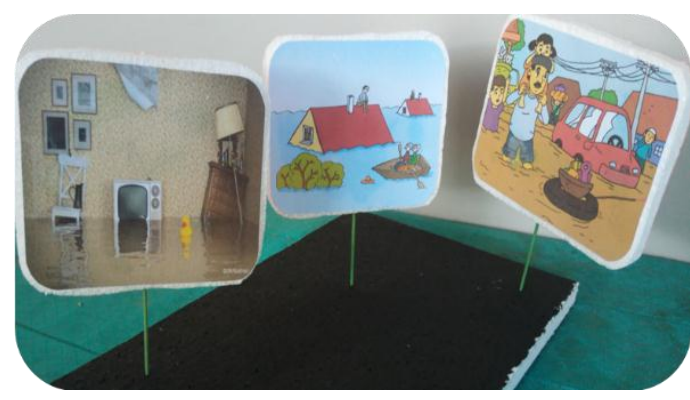

Gambar Materi (Peristiwa Banjir)

Setelah mengembangkan naskah media dan materi pembelajaran menjadi bentuk nyata yang akan digunakan dalam pembelajaran, tahap selanjutnya adalah melakukan penilaian terhadap unit-unit

Tabel 1. Penilaian terhadap Media Pembelajaran

\begin{tabular}{|c|c|c|c|c|}
\hline No. & Aspek Media & Indikator & Hasil Penilaian & Keterangan \\
\hline 1. & Berbasis Budaya & $\begin{array}{l}\text { Media pembelajaran } \\
\text { menggambarkan budaya } \\
\text { Melayu Bangka Belitung }\end{array}$ & sesuai & $\begin{array}{c}\text { Layak } \\
\text { digunakan }\end{array}$ \\
\hline 2. & Kejelasan bentuk & $\begin{array}{l}\text { Media berbentuk seperti } \\
\text { dulang dan tudung saji } 80 \%\end{array}$ & sesuai & $\begin{array}{c}\text { Layak } \\
\text { digunakan }\end{array}$ \\
\hline 3. & Keamanan & $\begin{array}{l}\text { Alat dan bahan yang } \\
\text { digunakan dalam } \\
\text { pengembangan media aman } \\
\text { bagi siswa }\end{array}$ & sesuai & $\begin{array}{c}\text { Layak } \\
\text { digunakan }\end{array}$ \\
\hline 4. & Kemenarikan & $\begin{array}{l}\text { Penggunaan warna yang } \\
\text { menarik perhatian siswa }\end{array}$ & sesuai & $\begin{array}{c}\text { Layak } \\
\text { digunakan }\end{array}$ \\
\hline 5. & Kemudahan & $\begin{array}{l}\text { Guru dan siswa mudah } \\
\text { menggunakan media dalam } \\
\text { pembelajaran }\end{array}$ & sesuai & $\begin{array}{c}\text { Layak } \\
\text { digunakan }\end{array}$ \\
\hline 6. & Pemanfaatan sisi & $\begin{array}{lr}\text { Sisi-sisi pada } & \text { media } \\
\text { dimanfaatkan dengan } & \text { baik } \\
\text { untuk pembelajaran } & \end{array}$ & $\begin{array}{l}\text { Masih terdapat } \\
\text { sisi dulang dan } \\
\text { tudung saji yang } \\
\text { belum } \\
\text { dimanfaatkan } \\
\text { dengan baik } \\
\end{array}$ & $\begin{array}{l}\text { Layak setelah } \\
\text { perbaikan }\end{array}$ \\
\hline 7. & Ketahanan & $\begin{array}{l}\text { Alat dan bahan yang } \\
\text { digunakan dapat digunakan }>\end{array}$ & $\begin{array}{l}\text { Bahan yang } \\
\text { digunakan }\end{array}$ & $\begin{array}{l}\text { Layak setelah } \\
\text { perbaikan }\end{array}$ \\
\hline
\end{tabular}

prototipe yang siap digunakan. Pengujian dilakukan untuk melihat keterpakaian media maupun materi berdasarkan desain yang telah disusun.

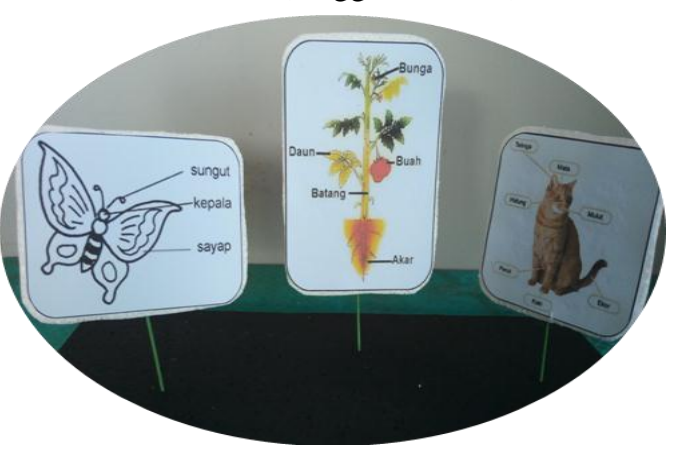

Gambar Materi (Bagian Tanaman dan Hewan)

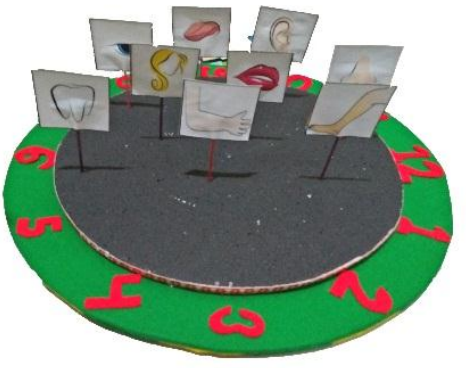

Gambar Materi (Anggota Tubuh) 


\begin{tabular}{|c|c|c|c|c|}
\hline No. & Aspek Media & Indikator & Hasil Penilaian & Keterangan \\
\hline & & 1 tahun ajaran & $\begin{array}{l}\text { sebagai alas } \\
\text { pada dulang } \\
\text { sebaiknya } \\
\text { menggunakan } \\
\text { bahan yang } \\
\text { lebih kuat agar } \\
\text { dulang tersebut } \\
\text { dapat bertahan } \\
\text { lama }\end{array}$ & \\
\hline
\end{tabular}

Berdasarkan tabel 1 di atas, dapat disimpulkan bahwa penilaian media pembelajaran terdiri atas sembilan aspek, yaitu berbasis budaya, kejelasan bentuk, keamanan, kemenarikan, kemudahan, pemanfaatan sisi, dan ketahanan. Hasil penilaian terhadap kesembilan aspek di atas, menggambarkan media pembelajaran yang dihasilkan memerlukan perbaikan di beberapa aspek, seperti pemanfaatan sisi, ketahanan bahan dan alat yang digunakan.

Pada asepek pemanfaatan sisi, masih ditemukan beberapa sisi yang belum dimanfaatkan dengan baik, seperti sisi pada tudung saji, terlihat kosong, sebaiknya diberikan asesoris atau materi pembelajaran yang sesuai. Selain pada aspek tersebut, ketahanan bahan dan alat layak digunakan setelah perbaikan, seperti penggunaan kardus untuk dulang sebaiknya menggunakan bahan yang lebih tebal sehingga mudah dianggung oleh siswa. Agar media pembelajaran dapat digunakan (layak pakai), maka pengembangan yang telah dilakukan harus direvisi// diperbaiki. Setelah perbaikan, maka akan dilakukan penilaian kembali oleh para ahli media tersebut.

Setelah media pembelajaran diuji oleh para ahli, langkah selanjutnya adalah penilaian terhadap pengembangan materi pembelajaran oleh para ahli materi. Hasil penilaian digambarkan pada tabel berikut.

Tabel 2. Penilaian terhadap Materi Pembelajaran

\begin{tabular}{|c|c|c|c|c|}
\hline & & & & \\
\hline No. & Aspek Materi & Indikator & Hasil Penilaian & Keterangan \\
\hline 1. & $\begin{array}{l}\text { Kesesuaian } \\
\text { Materi }\end{array}$ & $\begin{array}{l}\text { Materi yang disajikan } \\
\text { merupakan turunan KD }\end{array}$ & Sesuai & $\begin{array}{c}\text { Layak } \\
\text { digunakan }\end{array}$ \\
\hline 2. & Sistematis & $\begin{array}{l}\text { Materi yang disajikan } \\
\text { tersusun secara } \\
\text { sistematis }\end{array}$ & Sesuai & $\begin{array}{c}\text { Layak } \\
\text { digunakan }\end{array}$ \\
\hline 3. & Ketepatan Materi & $\begin{array}{l}\text { Materi yang disajikan } \\
\text { sesuai dengan } \\
\text { karakteristik siswa } \\
\text { kelas } 1\end{array}$ & Sesuai & $\begin{array}{c}\text { Layak } \\
\text { digunakan }\end{array}$ \\
\hline 4. & $\begin{array}{l}\text { Kejelasan } \\
\text { petunjuk } \\
\text { penggunaan } \\
\text { materi }\end{array}$ & $\begin{array}{l}\text { Materi yang disajikan } \\
\text { dilengkapi petunjuk } \\
\text { atau cara penggunaan }\end{array}$ & $\begin{array}{l}\text { petunjuk penggunaan } \\
\text { materi harus } \\
\text { memberikan } \\
\text { penjelasan secara rinci } \\
\text { agar pengguna } \\
\text { memahami dengan } \\
\text { baik }\end{array}$ & $\begin{array}{c}\text { Layak setelah } \\
\text { perbaikan }\end{array}$ \\
\hline 5. & $\begin{array}{l}\text { Keterkaitan } \\
\text { gambar terhadap } \\
\text { isi materi }\end{array}$ & $\begin{array}{l}\text { Gambar yang disajikan } \\
\text { sesuai dengan isi materi } \\
\text { pembelajaran }\end{array}$ & Sesuai & $\begin{array}{c}\text { Layak } \\
\text { digunakan }\end{array}$ \\
\hline 6. & Bentuk gambar & $\begin{array}{l}\text { gambar yang disajikan } \\
\text { tampak jelas dan } \\
\text { mudah dipahami }\end{array}$ & $\begin{array}{l}\text { Gambar yang disajikan } \\
\text { sebagai materi } \\
\text { pembelajaran dibentuk }\end{array}$ & $\begin{array}{c}\text { Layak setelah } \\
\text { perbaikan }\end{array}$ \\
\hline
\end{tabular}




\begin{tabular}{|c|c|c|c|c|}
\hline No. & Aspek Materi & Indikator & \begin{tabular}{l}
\multicolumn{1}{c}{ Hasil Penilaian } \\
dengan ukuran yang \\
lebih besar lagi agar \\
dapat terbaca oleh \\
semua siswa. \\
Gambar yang \\
dikembangkan dengan \\
menggunakan karton \\
sebaiknya \\
menggunakan \\
styrofoam agar terlihat \\
nyata.
\end{tabular} & Keterangan \\
\hline 7. & Kemenarikan & $\begin{array}{l}\text { Materi yang disajikan } \\
\text { menarik, mendorong, } \\
\text { dan memotivasi siswa } \\
\text { untuk berbicara }\end{array}$ & Sesuai & $\begin{array}{c}\text { Layak } \\
\text { digunakan }\end{array}$ \\
\hline
\end{tabular}

Tabel 2 di atas merupakan transkrip hasil penilaian para ahli terhadap materi pembelajaran berdasarkan instrumen penilaian. Dapat disimpulkan bahwa penilaian materi pembelajaran terdiri atas tujuh aspek, di antaranya kesesuaian materi, sistematis, ketepatan materi, kejelasan petunjuk penggunaan materi, keterkaitan gambar terhadap isi materi, bentuk gambar, dan kemenarikan.

Berdasarkan ketujuh aspek penilaian tersebut, terdapat beberapa aspek yang harus diperbaiki sehingga menghasilkan produk materi pembelajaran yang baik dan terpahami, seperti petunjuk penggunaan materi harus memberikan penjelasan secara rinci agar pengguna memahami dengan baik. Selain itu, bentuk gambar yang disajikan sebagai materi pembelajaran dicetak dengan ukuran yang lebih besar agar dapat terbaca oleh semua siswa. Selain itu, gambar yang dikembangkan dengan menggunakan karton sebaiknya menggunakan styrofoam agar terlihat nyata.

Berdasarkan hasil validitas media dan materi pembelajaran tersebut, dapat disimpulkan bahwa media dan materi pembelajaran sebagai alternatif pembelajaran berbicara siswa kelas 1 harus dilakukan perbaikan agar layak digunakan dalam pembelajaran. Oleh karena itu, langkah peneliti selanjutnya adalah memperbaiki aspek-aspek yang dinilai perlu perbaikan.

Setelah dilakukan perbaikan 1, maka media dan materi pembelajaran dinilai kembali oleh para ahli media dan materi. Hasil yang diperoleh digambarkan pada tabel berikut.

Tabel 3. Penilaian Kedua terhadap Media Pembelajaran

\begin{tabular}{|c|c|c|c|c|}
\hline No. & Aspek Media & Indikator & Hasil Penilaian & Keterangan \\
\hline 1. & Pemanfaatan sisi & $\begin{array}{lr}\text { Sisi-sisi pada } & \text { media } \\
\text { dimanfaatkan } & \text { dengan } \\
\text { baik } & \text { untuk } \\
\text { pembelajaran } & \\
\end{array}$ & $\begin{array}{l}\text { Sisi-sisi pada tudung } \\
\text { saji telah diperbaiki } \\
\text { sesuai saran }\end{array}$ & $\begin{array}{c}\text { Layak } \\
\text { digunakan }\end{array}$ \\
\hline 2. & Ketahanan & 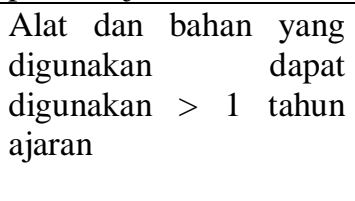 & $\begin{array}{c}\text { Bahan yang digunakan } \\
\text { pada dulang telah } \\
\text { diganti dengan karton } \\
\text { padi dengan tebal } 2 \\
\text { inci. }\end{array}$ & $\begin{array}{c}\text { Layak } \\
\text { digunakan }\end{array}$ \\
\hline
\end{tabular}

Tabel 4. Penilaian Kedua terhadap Materi Pembelajaran

\begin{tabular}{lllll}
\hline No. & Aspek Materi & Indikator & Hasil Penilaian & Keterangan \\
\hline
\end{tabular}




\begin{tabular}{|c|c|c|c|c|}
\hline No. & Aspek Materi & Indikator & Hasil Penilaian & Keterangan \\
\hline 1. & $\begin{array}{l}\text { Kejelasan } \\
\text { petunjuk } \\
\text { penggunaan } \\
\text { materi }\end{array}$ & $\begin{array}{l}\text { Materi yang disajikan } \\
\text { dilengkapi petunjuk } \\
\text { atau cara penggunaan }\end{array}$ & $\begin{array}{l}\text { Petunjuk penggunaan } \\
\text { telah dirinci secara jelas } \\
\text { sehingga pengguna } \\
\text { selain pengembang dapat } \\
\text { memahami alur } \\
\text { pembelajaran dengan } \\
\text { baik }\end{array}$ & $\begin{array}{c}\text { Layak } \\
\text { digunakan }\end{array}$ \\
\hline 2. & Bentuk gambar & $\begin{array}{l}\text { gambar yang disajikan } \\
\text { tampak jelas dan } \\
\text { mudah dipahami }\end{array}$ & $\begin{array}{l}\text { Gambar sebagai materi } \\
\text { pembelajaran telah } \\
\text { diperbesar dan } \\
\text { menggunakan styrofoam } \\
\text { sebagai penopang materi. }\end{array}$ & $\begin{array}{c}\text { Layak } \\
\text { digunakan }\end{array}$ \\
\hline
\end{tabular}

Berdasarkan penilaian kedua yang telah dilakukan baik terhadap media maupun materi pembelajaran dapat disimpulkan bahwa pengembangan media pembelajaran Nganggung layak digunakan sebagai alternatif pembelajaran berbicara di kelas rendah.

\section{SIMPULAN}

Berdasarkan hasil penelitian dan pembahasan yang telah diuraikan dapat disimpulkan bahwa kemampuan berbicara siswa kelas rendah selama pembelajaran belum tampak aktif seperti yang telah direncanakan dalam dokumen perencanaan. Hal tersebut disebabkan kurangnya kreativitas guru dalam mengembangkan metode dan media pembelajaran dari yang membuat siswa termotivasi untuk aktif berbicara. Berdasarkan gambaran tersebut, maka dirancanglah sebuah media "Nganggung" sebagai alternatif yang dapat membantu siswa dalam berbicara. Media tersebut dinilai oleh para ahli yang menyatakan bahwa layak digunakan sebagai alternatif pembelajaran berbicara di kelas rendah.

\section{DAFTAR PUSTAKA}

Arsyad, A. (2002). Media pembelajaran. Jakarta : PT. Raja Grafindo Persada.

I Wayan Sudiyana. Pengaruh implementasi model pembelajaran bermain peran terhadap kemampuan berbicara ditinjau dari bakat verbal siswa kelas XI SMA N 2 Bangli. Bandung: Jurnal UPI.
Peraturan Pemerintah Republik Indonesia Nomor 19 Tahun 2005 Tentang Standar Nasional Pendidikan. Jakarta: Depdiknas.

Prihatiningsih. (2009). "Peningkatan kemampuan berbicara dengan menggunakan media gambar seri pada siswa kelas VI SD N Jekani 1 Kecamatan Mondokan Kabupaten Sragen." Surakarta: FKIP Universitas Muhammadiyah Surakarta.

Resmini, N., dan Juanda, D. (2007). Pendidikan bahasa dan sastra Indonesia di kelas tinggi. Bandung: UPI Press.

Roestiyah N.K. (2008). Strategi belajar mengajar. Jakarta: Rineka Cipta.

Solchan, T.W., dkk. (2008). Pendidikan bahasa Indonesia di SD. Jakarta: Universitas Terbuka.

Sudikan. (2001). Metode penelitian kebudayaan. Surabaya: Citra Wacana.

Sugiyono. (2012). Metode penelitian kuantitatif, kualitatif dan $R \& D$. Bandung: Alfabeta.

Tarigan, H.G. (2008). Berbicara sebagai suatu keterampilan berbahasa. Bandung: Angkasa.

Widawati, C. W. (2010). Dasar-dasar berbicara. Diakses dari http://colinawati.blog.uns.ac.id. Diunduh pada 15 April 2013.

Widyantoro. S. (2011). pembelajaran keterampilan berbicara melalui pendekatan pengalaman berbahasa 
171 Jurnal Pemikiran dan Pengembangan SD, Volume 6, Nomor 2, September 2018 hlm 162-171

di Sekolah Dasar. Available online at: http//www.staf.uny.ac.id. 